Full length article

\title{
N-hexanoyl-L-homoserine lactone-degrading Pseudomonas aeruginosa PsDAHP1 protects zebrafish against Vibrio parahaemolyticus infection
}

\author{
Gopalakrishnan Vinoj ${ }^{\mathrm{a}}$, Rengarajan Jayakumar ${ }^{\mathrm{b}}$, Jiann-Chu Chen ${ }^{\mathrm{c}}$, \\ Boonsirm Withyachumnarnkul ${ }^{\mathrm{d}, \mathrm{e}}$, Sathappan Shanthi ${ }^{\mathrm{a}}$, Baskaralingam Vaseeharan ${ }^{\mathrm{a}, \text { * }}$ \\ a Crustacean Molecular Biology and Genomics Lab, Department of Animal Health and Management, Alagappa University, Karaikudi 630 004, \\ Tamil Nadu, India \\ ${ }^{\mathrm{b}}$ Central Marine Fisheries Research Institute (CMFRI), Marine Fisheries Post, Mandapam Camp, 623520 Tamil Nadu, India \\ ${ }^{c}$ Department of Aquaculture, College of Life Sciences, National Taiwan Ocean University, 202, Keelung, Taiwan, ROC \\ ${ }^{\mathrm{d}}$ Center of Excellence for Shrimp Molecular Biology and Biotechnology (Centex Shrimp), Mahidol University, Bangkok 10400, Thailand \\ e Aquatic Animal Biotechnology Research Center, Faculty of Science and Industrial Technology, Prince of Songkla University, Surat Thani Campus, \\ Surat Thani 84100 , Thailand
}

\section{A R T I C L E I N F O}

\section{Article history:}

Received 3 April 2014

Received in revised form

23 October 2014

Accepted 28 October 2014

Available online 6 November 2014

\section{Keywords:}

Biofilm

Pseudomonas

Green fluorescent protein

AHL

zebrafish

\begin{abstract}
A B S T R A C T
Four strains of N-hexanoyl-L-homoserine lactone (AHL)-degrading Pseudomonas spp., named PsDAHP1, PsDAHP2, PsDAHP3, and PsDAHP4 were isolated and identified from the intestine of Fenneropenaeus indicus. PsDAHP1 showed the highest AHL-degrading activity among the four isolates. PsDAHP1 inhibited biofilm-forming exopolysaccharide and altered cell surface hydrophobicity of virulent green fluorescent protein (GFP)-tagged Vibrio parahaemolyticus DAHV2 (GFP-VpDAHV2). Oral administration of PsDAHP1 significantly reduced zebrafish mortality caused by GFP-VpDAHV2 challenge, and inhibited colonisation of GFP-VpDAHV2 in the gills and intestine of zebrafish as evidence by confocal laser scanning microscope and selective plating. Furthermore, zebrafish receiving PsDAHP1-containing feed had increased phagocytic cells of its leucocytes, increased serum activities of superoxide dismutase and lysozyme. The results suggest that Pseudomonas aeruginosa PsDAHP1 could protect zebrafish from $V$. parahaemolyticus infection by inhibiting biofilm formation and enhancing defence mechanisms of the fish.
\end{abstract}

(C) 2014 Elsevier Ltd. All rights reserved.

\section{Introduction}

Diseases caused by biofilm formation of Vibrio spp. can be problematic in intensive shrimp farming and lead to economic loss, especially in nursery [1]. Current problem of acute hepatopancreatic necrosis disease caused by Vibrio parahaemolyticus results in a severe blow to the shrimp farming industry [2]. Skin haemorrhages, necroses and mortality have also been observed in V. parahaemolyticus infected fish [3]. The underlying pathogenesis caused by Vibrio infection in shrimp and fish are, however, not well understood. In experimentally-infected rabbits, it was reported that flagellae and pili of $V$. parahaemolyticus were adhered and formed biofilm in the gut epithelium of the animals [4]. The bacteria $V$. parahaemolyticus has been known to undergo reversible phase variation; and its architecture and integrity of strains form vigorous biofilms that are different from those of other Vibrio

\footnotetext{
* Corresponding author. Tel.: +91 4565 225682; fax: +91 4565225202.

E-mail address: vaseeharanb@gmail.com (B. Vaseeharan).
}

species, which is due to the amounts of capsular polysaccharide and other cell surface molecules [5]. The polysaccharides excreted from the bacterial cells, or exopolysaccharide, plays an important role in the aggregation of the bacteria during biofilm formation [6]. Interfering with the biofilm formation of Vibrio spp. is one way to disrupt quorum sensing and serves as an alternative to the use of antibiotics [7]. Non-antibiotic molecules are naturally produced within bacterial communities; these include signalling molecules or surface active biosurfactants that interfere with biofilm formation [8].

Therefore, disruption of quorum sensing has been suggested as a new strategy to control bacterial infection in aquaculture [9]. For instance, Pseudomonas spp. produces bacteriocins, pyocin, and phenazinen which are used as bioactive agents and two Pseudomonas strains, PAI-A and PA01, were found to degrade 3oxododecanoyl homoserine lactone and other long-acyl groups; the bacteria use the substance as an energy source [10].

Probiotics have been widely used in aquaculture to prevent bacterial infections [11], however, the mechanisms by which probiotics could control virulence of the pathogens are not well 
understood. Probiotics have been shown to enhance phagocytic activity, increase production of reactive oxygen species by macrophages, increase immunoglobulin-producing cells and acidophilic granulocytes in fish and shrimp [12]. It is also possible that the action of probiotics is on the disruption of the quorum sensing of bacterial pathogens, the mechanism of which has been underinvestigated thus far. In an attempt to isolate viable and potential quorum quenching strains of bacteria, we report mechanisms by which an acylated homoserine lactone (AHL)-degrading Pseudomonas aeruginosa, PsDAHP1 strain, protected zebrafish against $V$. parahaemolyticus challenge.

\section{Materials \& methods}

\subsection{Culture of AHL-degrading Pseudomonas spp. and virulent $V$. parahaemolyticus tagged with green fluorescent protein (GFP)}

The bacteria Pseudomonas spp. were isolated from intestine of healthy Indian shrimp Fenneropenaeus indicus collected from the Cuddalore coast, $250 \mathrm{~km}$ south of Chennai south-east coast of India. The bacterial strains were incubated on minimal media agar plates containing $\left(10^{6} \mathrm{CFU} \mathrm{ml}{ }^{-1}\right)$ with $5 \mathrm{mg} \mathrm{l}^{-1}$ of N-hexanoyl-L-homoserine lactone (C6-HSL) as sole carbon and nitrogen sources for $48 \mathrm{~h}$, at $30{ }^{\circ} \mathrm{C}$ [13]. The bacteria were further cultured and maintained in Zobell marine agar (ZMA) and broth (ZMB) (Himedia Laboratories, India). Three virulent strains of $V$. parahaemolyticus: VpDAHV1 (HQ693275), VpDAHV2 (HQ625651), and VpDAHV3 (HQ693276), isolated from $F$. indicus with black-gill disease were used as challenging bacteria. A non-virulent $V$. parahaemolyticus strain, ATCC 17802, was used as reference. The isolated strains of $V$. parahaemolyticus were cultured in tryptic soy agar and broth at $30{ }^{\circ} \mathrm{C}$ for $24 \mathrm{~h}$. One strain of $V$. parahaemolyticus, VpDAHV2, was tagged with green fluorescent protein (GFP) by conjugal transfer of pVSV102 $\left(\mathrm{Km}^{\mathrm{R}}\right)$, and GFP expression confirmed by confocal laser scanning microscopy (LSM 710, Carl Zeiss, Germany) [14]. Two strains of Chromobacterium violaceum (ATCC 12472 and CV026), being cultured in Luria-Bertani (LB) broth at $33{ }^{\circ} \mathrm{C}$, were used to determine quorum sensing inhibitory activity.

\subsection{Effect of cell-free Pseudomonas extracts on biofilm formation}

Cell-free extracts of four strains of Pseudomonas spp. (PsDAHP1, PsDAHP2, PsDAHP3 and PsDAHP4) were tested for their ability to inhibit $V$. parahaemolyticus biofilm formation in microtitre plates [15]. The bacteria, $\sim 10^{8}$ cells $\mathrm{ml}^{-1}$, were ultrasonicated using a UP100H ultrasonic processor (Hielscher, Germany) at 100 Watts for $1 \mathrm{~min}$. They were centrifuged at $800 \times \mathrm{g}$ for $10 \mathrm{~min}$, passed through a $0.2 \mu \mathrm{m}$ pore-sized filter and stored at $-20^{\circ} \mathrm{C}$. The virulent strains of $V$. parahaemolyticus (VpDAHV1, VpDAHV2, VpDAHV3) and the reference one (ATCC 17802), at $\sim 10^{6}$ cells $\mathrm{ml}^{-1}$, were inoculated into 96-well polystyrene microtitre plates containing $100 \mu \mathrm{l}$ of Zobell marine broth and $50 \mu \mathrm{l}$ of the Pseudomonas cell-free extracts for $24 \mathrm{~h}$ at $30{ }^{\circ} \mathrm{C}$. The cultures were discarded and the wells gently rinsed twice with deionised water and air-dried. The wells were then stained with $210 \mu \mathrm{l}$ of $0.1 \%(\mathrm{w} / \mathrm{v}$ ) crystal violet for $10 \mathrm{~min}$, rinsed with deionised water and air-dried. The dye was then eluted with $210 \mu$ l dimethyl sulfoxide and the amount of dye remained was determined at optical density of $595 \mathrm{~nm}$, using a Bio-Rad enzyme-linked immunosorbent assay reader (California, USA).

To visualize biofilm, the four strains of $V$. parahaemolyticus (VpDAHV1, VpDAHV2, VpDAHV3 and ATCC 17802) were allowed to grow on two set of glass pieces $(1 \times 1 \mathrm{~cm})$, which were placed in 24 well polystyrene plates supplemented with the cell-free extracts $(50 \mu \mathrm{l})$ of each of the four isolates of Pseudomonas spp., and incubated for $24 \mathrm{~h}$ at $30^{\circ} \mathrm{C}$. The glass samples were stained with crystal violet, and the visible biofilm examined under a light microscope (Nikon Inverted Research Microscope ECLIPSE Ti 100, Japan). Another set of glass pieces with biofilms grown was rinsed with PBS, stained with acridine orange (0.1\%), and examined using a confocal laser scanning microscope (Carl Zeiss LSM 710) at $488 \mathrm{~nm}$ argon laser, with BP 500-640 band pass emission filter and Zen 2009 software (Carl Zeiss, Germany).

\subsection{Degradation of N-hexanoyl-L-homoserine lactone (C6-HSL) assay}

N-hexanoyl-L-homoserine lactone (C6-HSL) degradation activity of the cell-free extracts of the four isolates of Pseudomonas spp. (PsDAHP1, PsDAHP2, PsDAHP3 and PsDAHP4) was determined using C. violaceum CV026 as the reporter strain in a well-diffusion C6HSL bioassay following the method described earlier [16]. The substance, C6-HSL, was used as a test compound because it is the major signalling molecule that regulates the expression of virulence factors, biofilm maturation and extracellular protease expression of pathogens such as Aeromonas sp., Edwardsiella tarda and Vibrio sp. [17,18].

Agar plates were prepared by mixing $3 \mathrm{ml}$ overnight culture of CV026 in $20 \mathrm{ml} \mathrm{LB}$ agar which was then poured into petri dishes. After setting, a $5 \mathrm{~mm}$ diameter plug was removed from each plate to form a well for the assay. The AHL-lactonase reaction mixture containing $10 \mu \mathrm{l}$ of the extracts and $190 \mu \mathrm{l}$ of $24 \mathrm{nM}$ C6-HSL in $50 \mathrm{mM}$ phosphate buffer ( $\mathrm{pH} 8.0$ ) was incubated at $25^{\circ} \mathrm{C}$ for $45 \mathrm{~min}$ before termination by addition of $50 \mu \mathrm{l}$ of $10 \% \mathrm{w} / \mathrm{v}$ sodium dodecyl sulphate (SDS). The reaction mixture was then transferred into the prepared plate wells, and the radius of CV026 growth after $24 \mathrm{~h}$ was used to determine residual C6-HSL levels. One unit of AHL-lactonase activity is defined as the amount of enzyme required to hydrolyse 1 nM C6HSL per min under the conditions described. AHL-lactonase activity was reported as the degradation rate of AHL in $\mathrm{mg} \mathrm{l}^{-1} \mathrm{~h}^{-1}$.

\subsection{Microbial adhesion to hydrocarbon assay}

Effects of the cell-free Pseudomonas extracts on cell surface hydrophobicity of GFP-VpDAHV2 were evaluated using a microbial adhesion to hydrocarbon assay. The bacteria GFP-VpDAHV2 (1 mlOD530) were placed into glass tubes, and mixed with $100 \mu \mathrm{l}$ of toluene, $50 \mu \mathrm{l}$ of each of the extracts. The mixture was then allowed

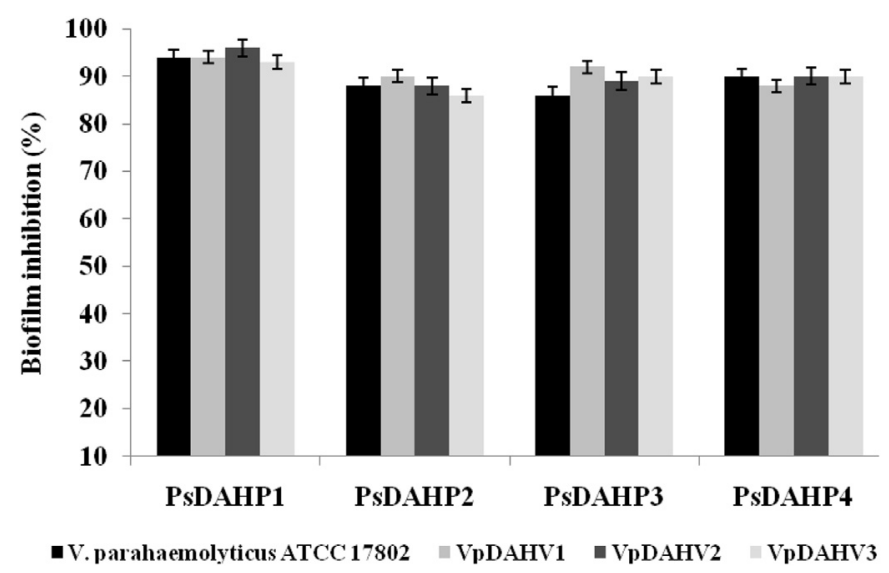

Fig. 1. Biofilm inhibition (\%) of PsDAHP1, PsDAHP2, PsDAHP3 and PsDAHP4 against V. parahaemolyticus ATCC 17802, VpDAHV1, VpDAHV2 and VpDAHV3 at concentration $50 \mu$ l of extracts, quantified by crystal violet adsorption and measuring absorbance at $570 \mathrm{~nm}$. Mean values of triplicate individual experiments and SDs are shown. Dunnett's test demonstrates significant difference between the treated and the control $(p<0.05)$. 
to settle for $30 \mathrm{~min}$, and optical density of the aqueous phase was determined by a spectrophotometer (UV1800 Shimadzu, Japan). Hydrophobicity index of GFP-VpDAHV2 was calculated based on the formula described [19].

\subsection{Quantification of exopolysaccharide}

The level of exopolysaccharide produced by $V$. parahaemolyticus was determined by carbohydrate assay. Sterile glass pieces were immersed in GFP-VpDAHV2 culture containing $50 \mu \mathrm{l}$ of each of the Pseudomonas extracts or Zobell broth (control) in 24-well polystyrene plates, and incubated for $24 \mathrm{~h}$. The glass slides were rinsed with $0.9 \% \mathrm{NaCl}$ solution and cell suspensions in the solution were transferred to test tubes with an equal volume of $5 \%$ phenol, to which 5 volumes of sulphuric acid containing $0.2 \%$ of hydrazine sulphate were added. The mixture was incubated in darkness for $1 \mathrm{~h}$, centrifuged at $10,000 \times \mathrm{g}$ for $10 \mathrm{~min}$, and optical density of the supernatant determined at $490 \mathrm{~nm}$.

\subsection{Assessment of biofilm metabolic activity}

To each of the microtitre plate wells containing Pseudomonas extracts and GFP-VpDAHV2 mature biofilm, $900 \mu \mathrm{l}$ of fresh ZMB broth, $90 \mu \mathrm{l}$ of XTT-2,3-bis (2-methoxy-4-nitro-5-sulfophenyl)-5- [(phenyl amino) carbonyl]-2H-tetrazolium hydroxide salt solution (1 $\mathrm{mg} / \mathrm{ml}$ ) (Sigma Aldrich, St. Louis, MO), and $10 \mu \mathrm{l}$ menadione solution ( $1 \mathrm{mM}$ ) were added. The wells were incubated in darkness at $28{ }^{\circ} \mathrm{C}$ for $5 \mathrm{~h}$. XTT tetrazolium salt was reduced to XTT formazan, and formed violet color. The wells were then placed on a spectrophotometer and the optical density measured at $490 \mathrm{~nm}$ [20].

\subsection{Confocal laser scanning microscope observation of GFP- VpDAHV2 biofilm inhibition by cell-free extract of PsDAHP1}

In 24-well polystyrene plates, GFP-VpDAHV2 was incubated with PsDAHP1 cell-free extract $(50 \mu \mathrm{l})$ and glass pieces at $30^{\circ} \mathrm{C}$ for $24 \mathrm{~h}$. Glass pieces incubated with GFP-VpDAHV2 was rinsed twice with PBS and the biofilms quantified using a confocal laser scanning microscope to image GFP signal from cover-slip samples. Biofilms were assessed using COMSAT software.

\subsection{Determination of the lethal dose of VpDAHV2 in zebrafish}

Zebrafish (120 days of age, with an average weight and length of $400 \mathrm{mg}$ and $2.5 \mathrm{~cm}$, respectively) were allowed to acclimatise for 30 days and used to test the virulence of GFP-VpDAHV2. The bacteria were incubated in TSB at $30^{\circ} \mathrm{C}$ for $24 \mathrm{~h}$, centrifuged at $5000 \times \mathrm{g}$ for $10 \mathrm{~min}$, and the harvested cells serially diluted in sterile saline to
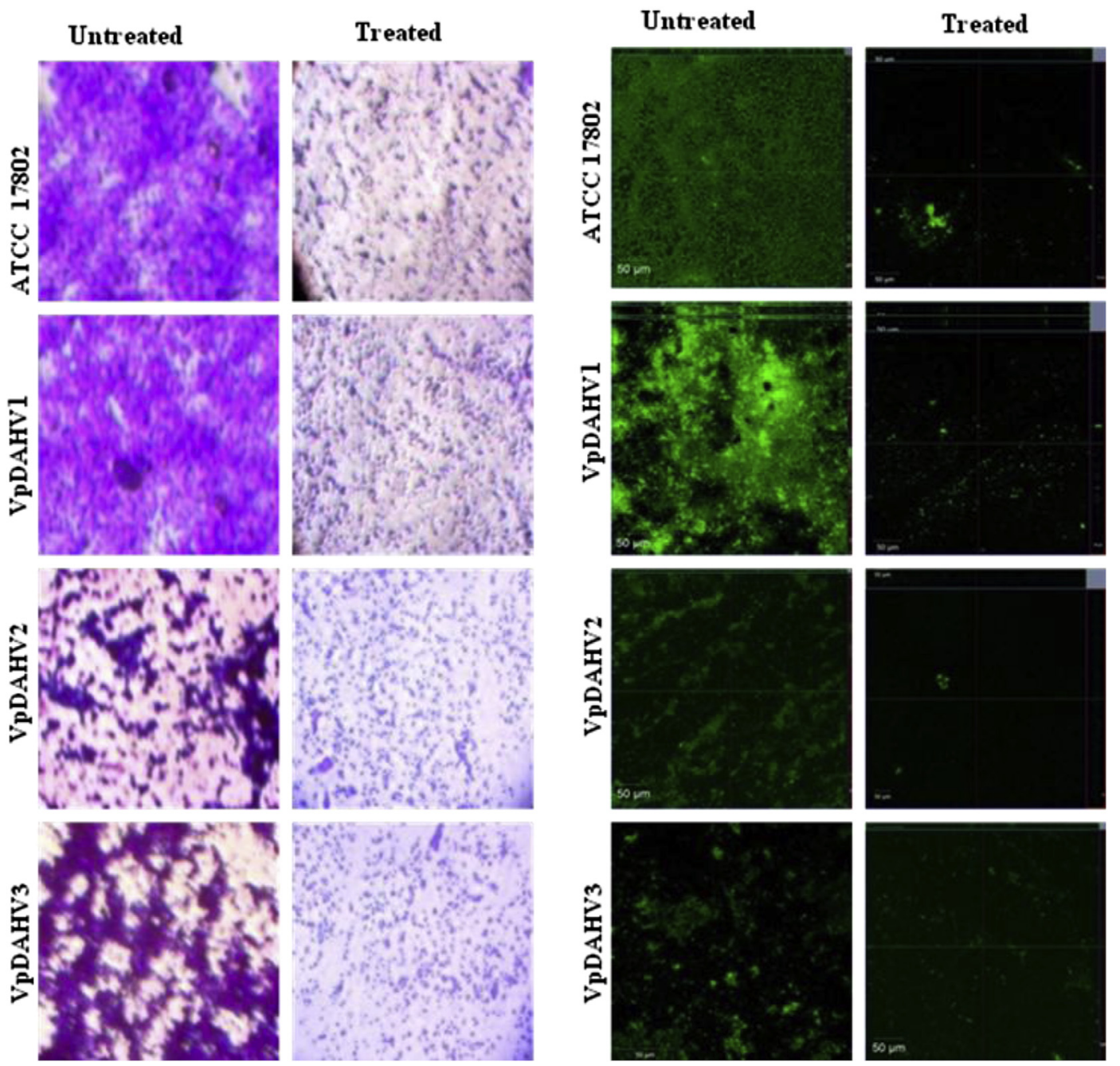

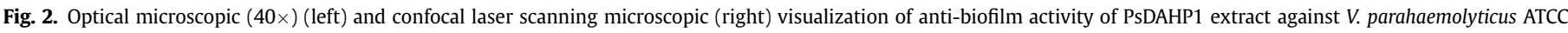
17802, VpDAHV1, VpDAHV2, and VpDAHV3. 
obtain $10^{3}$ to $10^{7}$ colony-forming units (CFU) $\mathrm{ml}^{-1}$. Aliquots of each dilution were plated on TSA to confirm the right concentrations in CFU $\mathrm{ml}^{-1}$. Zebrafish were immersed for $24 \mathrm{~h}$ in duplicate vessels containing $10^{3}, 10^{4}, 10^{5}, 10^{6}$ or $10^{7} \mathrm{CFU} \mathrm{ml}{ }^{-1}$ of GFP-VpDAHV2. After the immersion, the fish were released into the fibreglass reinforced plastics tank and mortality was recorded for 10 days [21]. Virulence of GFP-VpDAHV2 was determined based on $\mathrm{LD}_{50}$ which was calculated using the Probit method [22].

\subsection{Preparation of GFP-VpDAHV2 and PsDAHP1-mixed feed}

GFP-VpDAHV2 at $3 \times 10^{6} \mathrm{CFU} \mathrm{ml}^{-1}$ was found to be $\mathrm{LD}_{50}$ for zebrafish; this bacterial density was employed for $V$. parahaemolyticus challenge. Zebrafish were immersed into the challenging tank for $24 \mathrm{~h}$ at $3 \times 10^{6} \mathrm{CFU} \mathrm{ml}{ }^{-1}$. After challenge the zebrafish were released into the fibreglass reinforced plastics tank and the water exchange was carried out every 4 days. Pure culture of PsDAHP1 from an overnight growth on ZMA plates containing $10 \mathrm{ml}$ of ZMB were incubated at $30^{\circ} \mathrm{C}$ for $24 \mathrm{~h}$. After incubation, the cells were harvested by centrifugation at $2500 \times \mathrm{g}$ for $20 \mathrm{~min}$, washed twice with, and re-suspended in saline, in which the bacterial suspension was adjusted at $10^{8}$ cells $\mathrm{ml}^{-1}$. The PsDAHP1-mixed feed was prepared by gently spraying the required amount of bacterial suspension on the pre-mixed commercial feed, and mixed in a drum mixer to obtain a final concentration of $10^{8}$ cells $\mathrm{g}^{-1}$ feed. The feed was dried in a drying cabinet using an air blower at $38^{\circ} \mathrm{C}$ until moisture level was around $10 \%$. After air-drying, it was sieved into pellets of appropriate size and stored at $-20^{\circ} \mathrm{C}$ until needed within seven days. The viability of the PsDAHP1 was determined by counting the number of colonies plated on ZMA.

\subsection{Effect of PsDAHP1-mixed feed on VpDAHV2 infection of zebrafish}

Zebrafish were randomly divided into four groups of 50 animals each, with 3 replicates. They were (1) Group A ( $P$. aeruginosa control), being fed with PsDAHP1-containing feed and no challenge; (2) Group B (positive control), being fed with basal feed and challenged with GFP-VpDAHV2; (3) Group C (experimental group); being fed with PsDAHP1-containing feed and challenged with GFPVpDAHV2; and (4) Group D (negative control), being fed with basal feed and no challenge. Fish mortality was recorded daily for 30days [21], following the challenge; dead and moribund fish were removed and moribund fish examined for the presence of GFPVpDAHV2 in the gills and intestine.

The dissected gills and intestine were washed twice with sterile phosphate buffer solution (PBS) and the tissues were homogenised individually in $1 \mathrm{ml}$ sterile seawater and plated in ZMA medium

\section{Table 1}

N-hexanoyl-L-homoserine lactone (C6-HSL) degradation rate of selected AHLdegrading Pseudomonas isolates in LB medium supplemented with $5 \mathrm{mg} \mathrm{l}^{-1}$ C6HSL, GenBank sequence accession numbers of partial 16S rRNA sequences of the isolates and related strains sharing $100 \%$ sequence identity with the sequences of the isolates (based on NCBI BLAST).

\begin{tabular}{|c|c|c|c|}
\hline Strains & $\begin{array}{l}\text { C6-HSL degradation } \\
\left(\mathrm{mg} \mathrm{l}^{-1} \mathrm{~h}^{-1}\right)\end{array}$ & $\begin{array}{l}\text { Accession } \\
\text { number }\end{array}$ & Related strains \\
\hline PsDAHP1 & $1.5 \pm 0.75$ & HQ400663 & $\begin{array}{l}\text { Pseudomonas aeruginosa } \\
\text { LP8 (EU195558) }\end{array}$ \\
\hline PsDAHP2 & $0.6 \pm 0.3$ & HQ693274 & $\begin{array}{l}\text { Pseudomonas aeruginosa } \\
\text { R9 (JQ660017) }\end{array}$ \\
\hline PsDAHP3 & $0.5 \pm 0.25$ & HQ693277 & $\begin{array}{l}\text { Pseudomonas } \\
\text { sp QLD (JQ394932) }\end{array}$ \\
\hline PsDAHP4 & $0.6 \pm 0.3$ & HQ693272 & $\begin{array}{l}\text { Pseudomonas aeruginosa } \\
\text { R9-771 (JQ660017) }\end{array}$ \\
\hline
\end{tabular}

with $100 \mu \mathrm{g} \mathrm{ml}^{-1}$ kanamycin and overlaid on LB agar supplemented with $1 \% \mathrm{NaCl}$. The plates were incubated at $30{ }^{\circ} \mathrm{C}$ and colonies counted after $48 \mathrm{~h}$. Confocal laser scanning microscope was used to confirm the identity of colonies growing on selected plates as being GFP-VpDAHV2. The dissected gills and intestine were washed twice with PBS, placed in clean glass slide and validated for the colonisation of GFP-VpDAHV2, using $488 \mathrm{~nm}$ argon laser line scan for excitation with a multi-line argon laser and a band pass wavelength of 493-634 nm. For each experiment, an immersion dose of GFPVpDAHV2 was plated as control.

\subsection{Defence mechanisms in fish receiving PsDAHP1-mixed feed}

In a parallel set-up, the effect of PsDAHP1 on parameters relating to defence mechanisms of zebrafish was examined. Five fish were taken randomly from each group after 10, 20 and 30 days of feeding. They were anaesthetised in $0.02 \%$ benzocaine solution (Sigma Inc., St. Louis, MO, USA). Individual blood samples $(1.0-1.5 \mathrm{ml})$ were taken from the caudal vein using a heparinized syringe $(25 \mathrm{G})$ fitted with a needle.

Blood $(500 \mu \mathrm{l})$ from individual fish was mixed with $500 \mu \mathrm{l}$ of $\mathrm{AL}$ medium (AIM-V medium) and Leibovitz's L 15 medium (GIBCO BRL, Gaithersburg, MD, USA), streptomycin and penicillin. Percoll (55\%, Sigma Inc., St. Louis, MO, USA) was added and the mixture
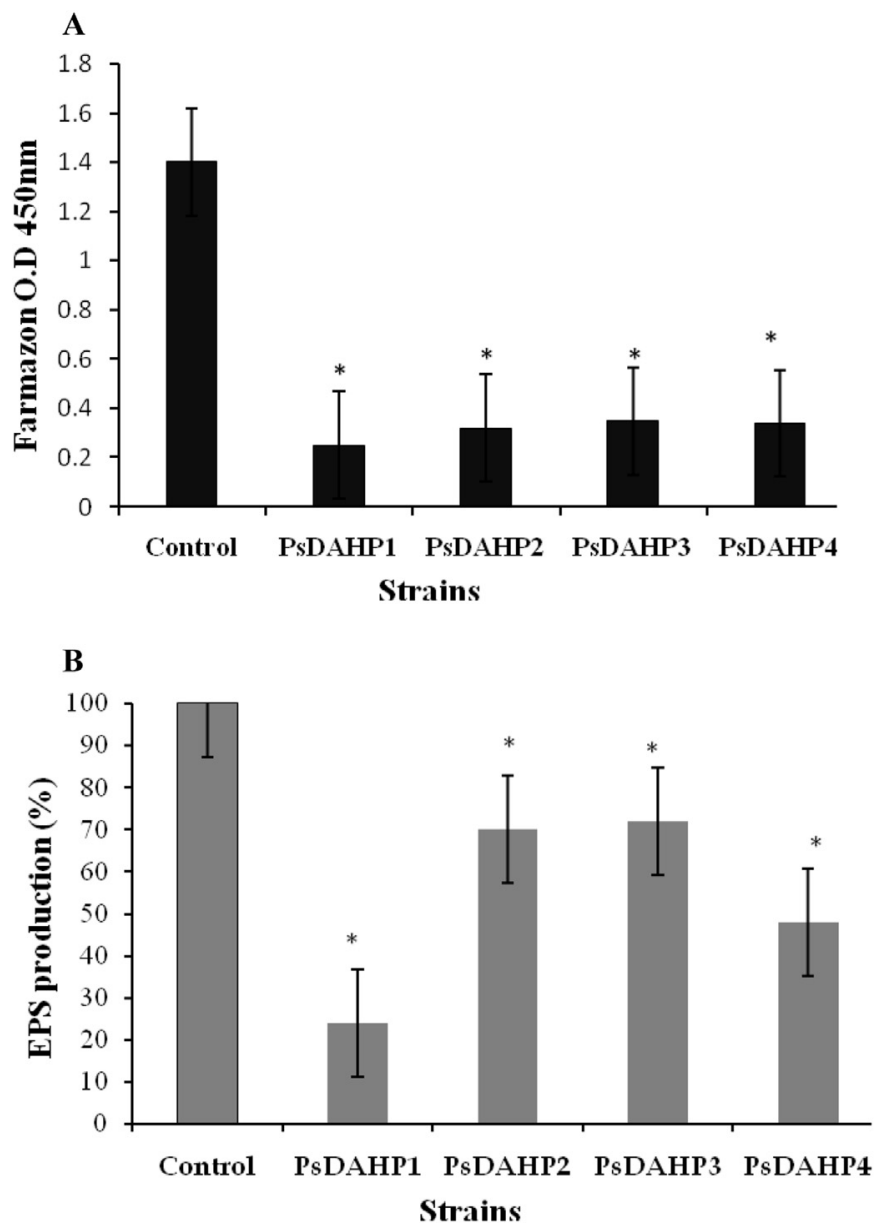

Fig. 3. PsDAHP1, PsDAHP2, PsDAHP3, and PsDAHP4 extracts inhibits the (A) metabolic activity and (B) Inhibition of exopolysaccharide (EPS) production of VpDAHV2 biofilm, as percentage of control. Experiments were performed in triplicates; mean \pm SD are shown. Dunnett's test demonstrates significant difference between the tests and the control, ${ }^{*}$ indicates statistical value $(p<0.05)$. 
centrifuged at $400 \times \mathrm{g}$ for $15 \mathrm{~min}$ at $10^{\circ} \mathrm{C}$. Leucocytes were obtained from the interface and washed with AL medium by centrifugation at $600 \times \mathrm{g}$ for $10 \mathrm{~min}$ at $10^{\circ} \mathrm{C}$. The leucocytes were then suspended in AL medium with $5.5 \mathrm{mM}$ glucose. Cell viability was analysed by trypan blue $(0.1 \%)$ with a haemocytometer.

For phagocytic cell test, $300 \mu \mathrm{l}$ of leucocyte suspension (in L-15 medium) in $10 \mathrm{ml}$ test tube, in triplicate, was added with $300 \mu \mathrm{l}$ of formalin-killed $V$. parahaemolyticus (in PBS) and the mixture was incubated for $1 \mathrm{~h}$ at $17^{\circ} \mathrm{C}$. Then, $900 \mu \mathrm{l}$ of cold PBS was added, and the tubes were centrifuged at $300 \times g$ for $5 \mathrm{~min}$. The supernatants were discarded and the pellets were smeared on slides. The slides were air-dried, stained with Giemsa solution (Sigma Inc., St. Louis, MO, USA) and the leucocytes were visualized and the number of phagocytic cells per 100 adhered cells was counted microscopically.

For superoxide dismutase (SOD) and lysozyme activity assay, the blood samples were collected into an Eppendorf tube and centrifuged at $1500 \times \mathrm{g}$ for $10 \mathrm{~min}$ at $4{ }^{\circ} \mathrm{C}$. The serum samples were pooled and stored at $-20^{\circ} \mathrm{C}$.

Superoxide dismutase activity was determined by enzymatic assay method using a reagent kit (Sigma Inc., St. Louis, MO, USA). The reaction was based on its inhibitory effect on the rate of superoxide-dependant reduction of nitroblue tetrazolium (NBT) by xanthine-xanthine oxidase that was determined with a spectrophotometer at $550 \mathrm{~nm}$. One unit of SOD activity was defined as the amount of enzyme necessary to produce $50 \%$ inhibition of the NBT reduction rate measured at $550 \mathrm{~nm}$.

For lysozyme activity assay, $50 \mu$ of the serum was mixed with $950 \mu \mathrm{l}$ of Micrococcus lysodeikticus (Sigma Inc., St. Louis, MO, USA) in
$0.05 \mathrm{M}$ PBS ( $\mathrm{pH}$ 6.2). The mixture was incubated at $25^{\circ} \mathrm{C}$, and optical density determined spectrophotometrically after $1 \mathrm{~min}$ and $6 \mathrm{~min}$ at $530 \mathrm{~nm}$. One unit of lysozyme activity was defined as the amount of enzyme producing a decrease in absorbance of $0.001 \mathrm{~min}^{-1} \mathrm{ml}^{-1}$ serum [23].

\subsection{Statistical analysis}

All assays were repeated at least three times, and all statistical analyses were performed using SPSS. Values were expressed as means $\pm \mathrm{SD}$. Mean values were compared using one way ANOVA.

\section{Results}

\subsection{In vitro screening of AHL-degrading Pseudomonas extract against V. parahaemolyticus biofilm}

Four strains of AHL-degrading Pseudomonas spp. were identified based on 16S rRNA gene sequencing, namely $P$. aeruginosa HQ400663 (PsDAHP1), P. aeruginosa HQ693274 (PsDAHP2), Pseudomonas sp. HQ693275 (PsDAHP3) and P. aeruginosa HQ693272 (PsDAHP4) and the sequences were submitted to NCBI GenBank (accession numbers were HQ400663, HQ693274, HQ693277 and HQ693272) respectively. Cell-free extracts, $50 \mu \mathrm{l}$, of the four Pseudomonas spp. were screened for their ability to interrupt $V$. parahaemolyticus biofilm formation using crystal violet staining in a microtitre plate-based assay. All the extracts could suppress more than $80 \%$ of biofilm formation by ATCC 17802 , VpDAHV1, VpDAHV2, and VpDAHV3 and highest suppression was obtained
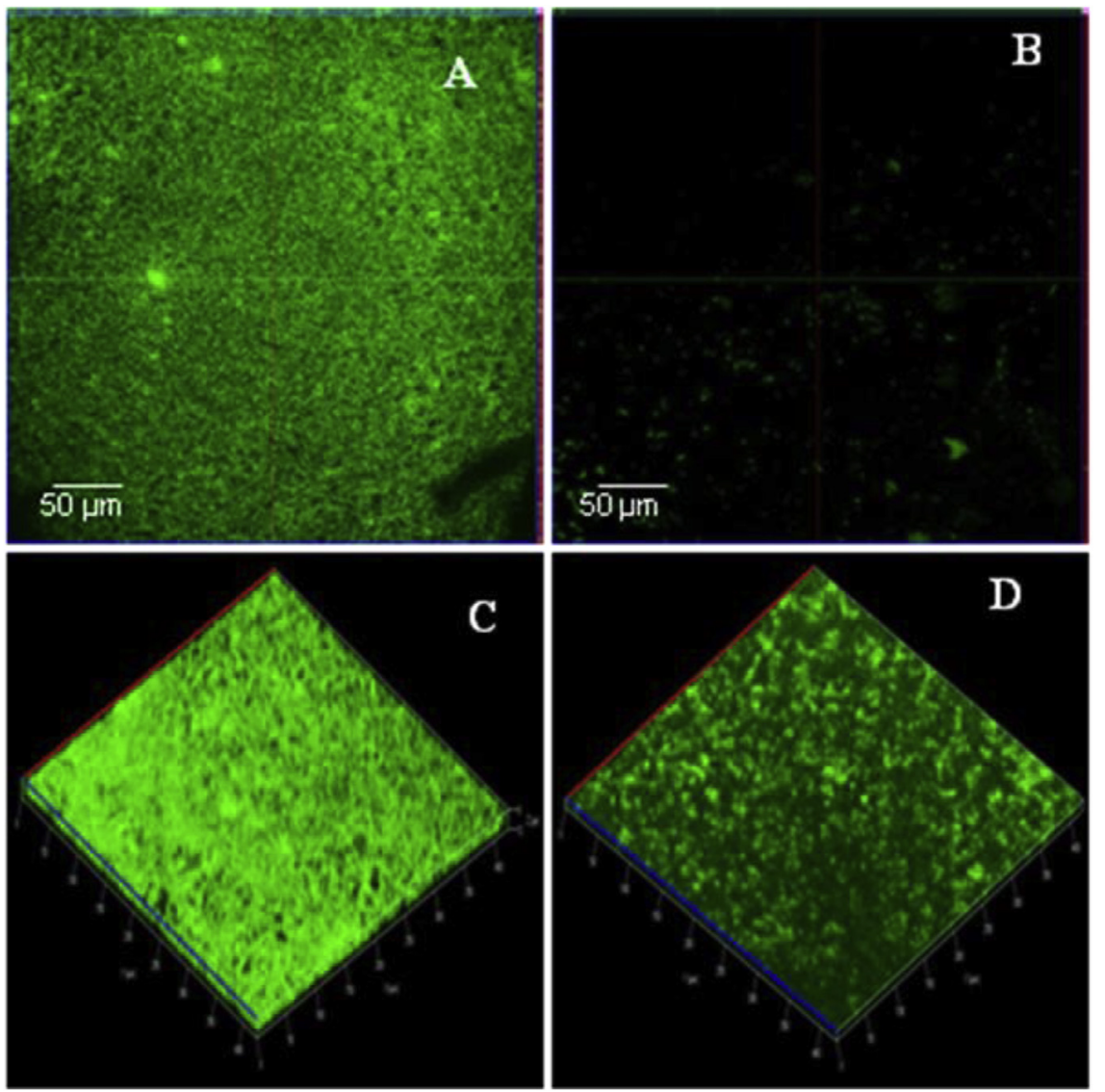

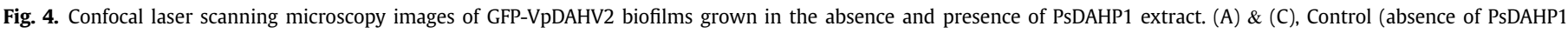
extract), 2D image; (B) \& (D) GFP-VpDAHV2 + PsDAHP1extract, 3D image. 
Table 2

Mortalities of zebrafish with different dose of GFP-VpDAHV2.

\begin{tabular}{llcc}
\hline Strain & $\begin{array}{l}\text { Dose } \\
(\text { CFU ml }\end{array}$ & $\begin{array}{l}\text { Mortality }(\%) \\
(\text { mean } \pm \mathrm{SD})\end{array}$ & $\mathrm{LD}_{50}\left(\mathrm{CFU} \mathrm{ml}^{-1}\right)$ \\
\hline VpDAHV2 & $10^{3}$ & $13.2 \pm 0.66$ & $\sim 3 \times 10^{6}$ \\
& $10^{4}$ & $25.3 \pm 1.26$ & \\
& $10^{5}$ & $39.2 \pm 1.96$ & \\
& $10^{6}$ & $48.2 \pm 2.41$ & \\
& $10^{7}$ & $69.2 \pm 3.46$ & \\
& $10^{8}$ & $72 \pm 3.6$ & \\
\hline
\end{tabular}

with PsDAHP1 extract (Fig. 1). Under light and confocal laser scanning microscopy, reduction in micro-colony formation in the four strains of $V$. parahaemolyticus was observed when treated with the cell-free extracts (Fig. 2). Among the four strains of V. parahaemolyticus tested, VpDAHV2 and ATCC 17802 were found to be potential biofilm formers, while the other two had lesser potential (data not shown). Therefore, in this study, VpDAHV2 was selected for further studies.

\subsection{Degradation of C6-HSL assay}

All the Pseudomonas cell-free extracts were able to degrade C6HSL. Among the four, that of PsDAHP1 had maximum effect, with $1.5 \mathrm{mg}$ C6-HSL degradation $\mathrm{l}^{-1} \mathrm{~h}^{-1}$ within $4 \mathrm{~h}$, about 3 times higher than the extracts from other strains (Table 1 ).

\subsection{Microbial adhesion to hydrocarbon and XTT assay (2, 3-Bis-(2- Methoxy-4-Nitro-5-Sulfophenyl)-2H-Tetrazolium-5-Carboxanilide)}

Cell-free extracts of all the AHL-degrading Pseudomonas sp. (PsDAHP1, PsDAHP2, PsDAHP3, and PsDAHP4) were screened for their activities on hydrophobicity index. At $50 \mu$ l concentration, the extracts reduced the hydrophobicity index of the GFP-VpDAHV2 from $61 \pm 0.94 \%$ to $21 \pm 0.96 \%, 38 \pm 0.84 \%, 41 \pm 0.63 \%, 30 \pm 0.6 \%$ in groups treated with PsDAHP1, PsDAHP2, PsDAHP3 and PsDAHP4 extracts, respectively. XTT assay confirmed that all the extracts inhibited the activity of GFP-VpDAHV2 that resulted in decreased biomass in the GFP-VpDAHV2 biofilm (Fig. 3A), and maximum inhibition was observed in the PsDAHP1 activity.

\subsection{Estimation of exopolysaccharide production}

AHL-degrading Pseudomonas cell-free extracts were screened for their inhibitory activities on GFP-VpDAHV2 exopolysaccharide production. All the extracts inhibited exopolysaccharide production, with maximum inhibition by PsDAHP1 (Fig. 3B).

\subsection{Inhibition of GFP-VpDAHV2 biofilm}

Under confocal laser scanning microscope, with 2D and 3D images, PsDAHP1 extract showed significant inhibition of GFPVpDAHV2 biofilm formation, whereas, no inhibition was detected in the untreated GFP-VpDAHV2 group (Fig. 4). The thickness and biovolume of biofilm formed in the control slides were $48.5 \pm 2.45 \mu \mathrm{m}$ and $44.1 \pm 2.20 \mu \mathrm{m}^{3}$, respectively, whereas the values in the treated slides were $15.2 \pm 0.76 \mu \mathrm{m}$ and $0.8 \pm 0.04 \mu \mathrm{m}^{3}$, respectively.

\subsection{Effect of PsDAHP1-mixed feed on GFP-VpDAHV2 infection in the zebrafish}

Virulence of GFP-VpDAHV2 in zebrafish was confirmed by immersion challenge and the $\mathrm{LD}_{50}$ value was $3 \times 10^{6} \mathrm{CFU} \mathrm{ml}{ }^{-1}$ (Table 2). Using the $\mathrm{LD}_{50}$ dose to challenge the fish, mortality of the negative control and PsDAHP1-treated fish was found to be zero during the 30 days challenging period (Fig. 5). The positive control fish, treated with GFP-VpDAHV2, had mortality more than $70 \%$ at day 20 after the challenge, while the experimental group, receiving PsDAHP1-mixed feed, had mortality of $20 \%$ up to day 29 after the challenge.

After 30 days in culture, colonisation of GFP-VpDAHV2 was observed in the moribund zebrafish being challenged with GFPVpDAHV2 in the gills and intestine of the fish, as observed under confocal laser scanning microscope (Fig. 6). In the gills, GFPVpDAHV2 was mostly colonised in the lamellar region; whereas in the intestine, the colonisation was mostly in entire region. The

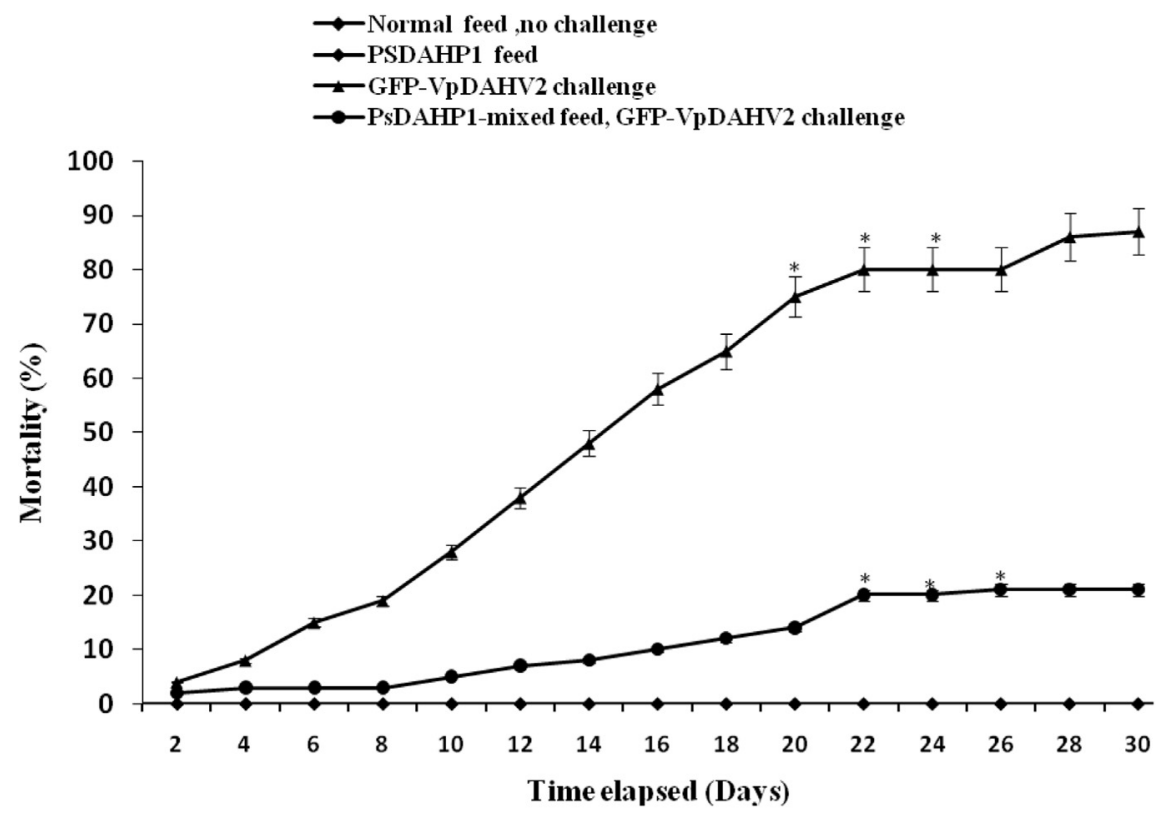

Fig. 5. Mortality rate of zebrafish in four groups of animals. Each point and error bar represents the mean of triplicate and standard deviation. 
GFP signal was markedly reduced in the fish given PsDAHP1-mixed pellets during the challenge. The results were confirmed by plate counts of GFP-VpDAHV2 at day 30 post-challenge, in which the bacterial counts in the gills $\left(4.1 \times 10^{4} \mathrm{CFU} \mathrm{g}^{-1}\right)$ and intestine $\left(5.4 \times 10^{4} \mathrm{CFU} \mathrm{g}^{-1}\right)$ of the challenged fish were markedly reduced in both tissues in PsDAHP1-treated group (gills, $0.9 \times 10^{2} \mathrm{CFU} \mathrm{g}^{-1}$; intestine, $1.2 \times 10^{2} \mathrm{CFU} \mathrm{g}^{-1}$ ).

\subsection{Fish defence mechanisms following PsDAHP1 administration}

Phagocytic cells of leucocytes of zebrafish fed with Pseudomonas-mixed feed for was evaluated for 30 days (Table 3). Initially without formalin-killed $V$. parahaemolyticus treated phagocyte cells in the fish receiving PsDAHP1 and control tank was $7 \pm 2 \%$ and $13 \pm 3 \%$ phagocytic cells respectively. Increased phagocytic cells were observed in leucocytes from all the fish that received the feed and highest rate was exhibited in the fish receiving PsDAHP1 ( $51 \pm 0.5 \%$ vs $40 \pm 1.5 \%$ in control, $p<0.05$ ).

Superoxide dismutase in the serum of the zebrafish receiving PsDAHP1-mixed feed was $23 \pm 0.1 \%$, while the level $11.0 \pm 0.5$ in the control group. Similarly, the lysozyme activity in the serum of the fish receiving PsDAHP1-mixed feed was also significantly $(p<0.05)$ higher than that of the control $(40 \pm 0.5 \%$ vs $18 \pm 0.2 \%$ in control).

\section{Discussion}

The present study represents the first report on inhibition of GFP-tagged $V$. parahaemolyticus VpDAHV2 colonisation and
Table 3

Defence mechanisms in fish receiving P. aeruginosa PsDAHP1 cell-free extracts.

\begin{tabular}{llll}
\hline Treatment & Phagocytic cell & $\begin{array}{l}\text { Superoxide } \\
\text { dismutase activity }\end{array}$ & Lysozyme activity \\
\hline $\begin{array}{c}\text { Not receiving } \\
\text { (control) }\end{array}$ & $40 \pm 1.5$ & $11 \pm 0.5$ & $18 \pm 0.2$ \\
PsDAHP1 & $51 \pm 0.5$ & $23 \pm 0.1$ & $40 \pm 0.5$ \\
\hline
\end{tabular}

immune modulatory effects of zebrafish received AHL-degrading $P$. aeruginosa PsDAHP1 cell-free extract. The bacteria V. parahaemolyticus could persist for a long time in aquatic habitats, and replicate in the host [24]. Inhibition of bacterial biofilm has been proposed as one of the most potential strategies for increasing the sensitivity of pathogens in biofilm to antibiotics. In the present study, among the four Pseudomonas spp. studied, cell-free extract of $P$. aeruginosa PsDAHP1 was able to degrade C6-HSL, microbial adhesion to hydrocarbon, exopolysaccharide and biofilm metabolic activity, resulting in a decreased biofilm formation by the virulent V. parahaemolyticus. The reduction of biofilm by Pseudomonas extracts was also revealed morphologically by confocal light scanning microscope, showing disintegrated architecture and reduced thickness. This study is similar to a recent report that the Bacillus licheniformis cell-free extract disperses Streptococcus aureus biofilm [25]. Hydrophobicity index is an imperative factor for cell accumulation and targeting the hydrophobicity index is a novel way of inhibiting biofilm formation. Thus, reduction in the hydrophobicity index reduces the accumulation of bacteria that leads to the inhibition of biofilm formation. From microscopic observation, it was
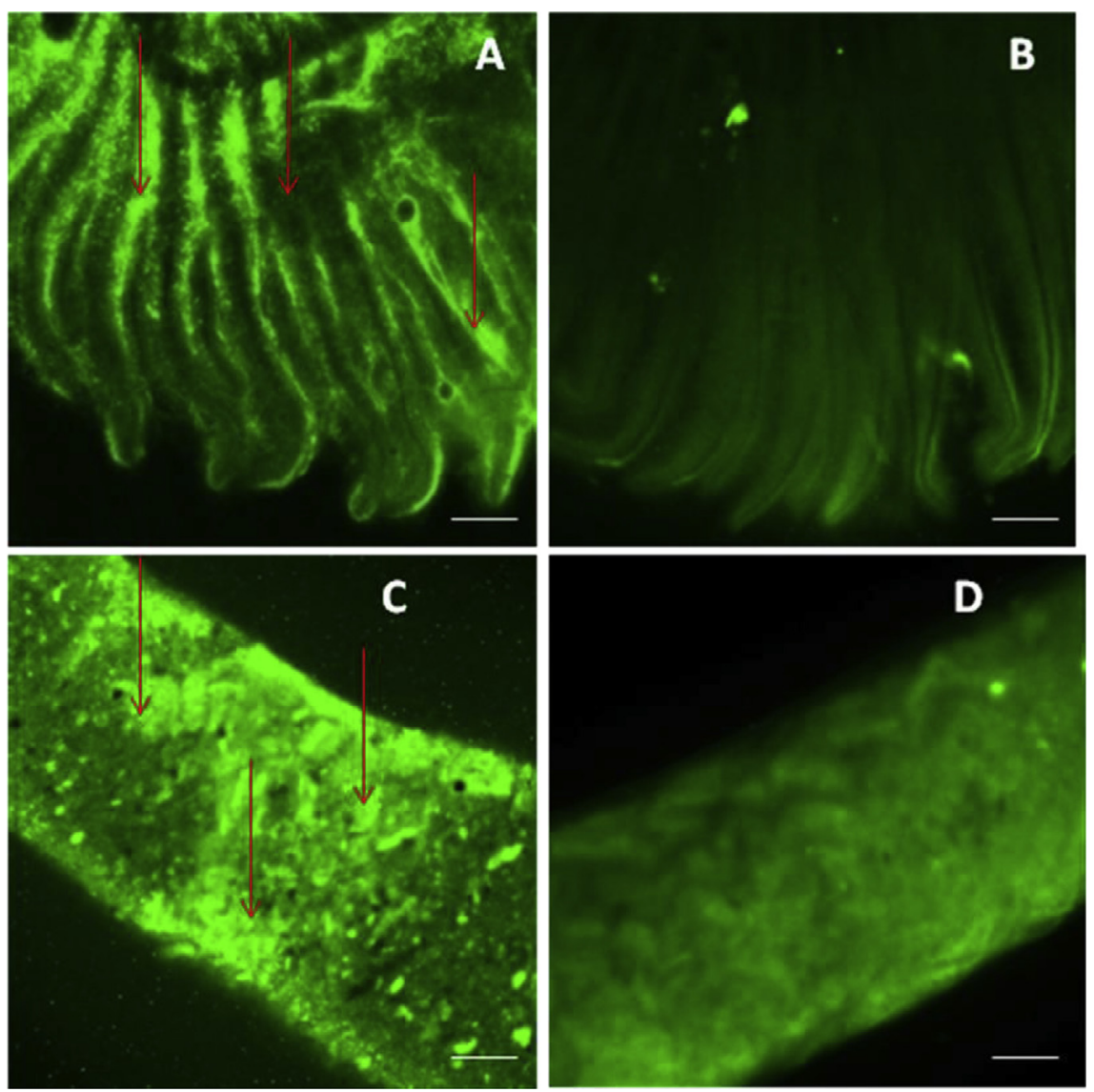

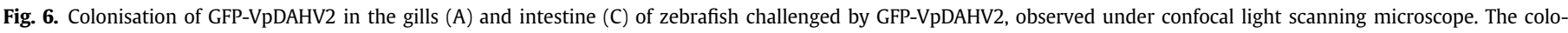
nisation was markedly decreased in the gills (B) and intestine (D) of the fish that were given PsDAHP1-mixed pellets. Arrow represents the colonisation of GFP-VpDAHV2. 
clear that the PsDAHP1 extract-treated biofilm architectures were looser than the control biofilm. Therefore, inhibition of hydrophobicity index and exopolysaccharide production by the PsDAHP1 cell-free extract slacked architecture of the GFP-VpDAHV2 microcolonies. This would make V. parahaemolyticus more susceptible to antibiotics that in turn will facilitate the eradication of biofilm.

Exopolysaccharide and cell surface hydrophobicity play an important role in bacterium-host cell interactions [26]. Previous studies reported that exopolysaccharide play a vital role in biofilm architectures in $V$. parahaemolyticus [27]. High level of the substance leads to alterations in biofilm architecture that correlate with an increased resistance to biocides such as chlorine [28,29].

By applying the benefits of using Pseudomonas cell-free extracts found in the in vitro findings into the in vivo study, we found that zebrafish receiving feed mixed with PsDAHP1 survived better than the control group. The result was also supported by the findings that phagocytic cells of the leucocytes, serum SOD and lysozyme activities and colonisation of the challenged bacteria $V$. parahaemolyticus was markedly reduced in the gills and intestine of the fish receiving PsDAHP1-mixed feed. The findings were in agreement with others in different species of fish, pathogens and probiotics [30]. For instance, SOD activity of tilapia significantly increased by Bacillus spp.-mixed feed [31], and lysozyme activity increased in rainbow trout that received Lactobacillus rhamnosus, Carnobacterium divergens, and Lactobacillus sakei [32]. Likewise, in grouper, Bacillus enhanced growth and immune responses [33]. Since both phagocytic cells of zebrafish and leucocytes and SOD and lysozyme activities were increased by PsDAHP1 in this study, it therefore suggests that PSDAHP1 could increase resistance in the fish through the stimulation of both physiological (phagocytic cells) and biochemical responses (SOD and lysozyme activity). It remains to find out what substance(s) released from PsDAHP1 is responsible for the induction of these responses.

While the search for the active substance(s) is on-going, it is possible to apply PsDAHP1-mixed feed in zebrafish to protect the fish against Vibrio infections, as it was also found in this study that PsDAHP1 had no adverse effect on the fish.

In conclusion, cell-free extract of $P$. aeruginosa PsDAHP1 was found to antagonise the actions of $V$. parahaemolyticus by suppressing AHL synthesis, biofilm formation, production of exopolysaccharide, and by modifying the adhesion properties of the pathogen. Moreover, oral administration of PsDAHP1-containing feed reduced mortality caused by $V$. parahaemolyticus challenge in zebrafish, enhanced leucocyte phagocytic cells, and serum activities of SOD and lysozyme in the fish. Moreover, PsDAHP1 had no adverse effect to the fish. AHL-degrading $P$. aeruginosa PsDAHP1 could control biofilm-associated infections caused by $V$. parahaemolyticus and enhance defence mechanisms of zebrafish.

\section{Acknowledgement}

This work was supported by University Grants Commission (Grant F. No. 36-5/2008(SR-) New Delhi, India. BV and JCC thanks the fund support by Indo-Taiwan programme of cooperation from Department of Science and Technology, New Delhi, India, (Project code ITRD003) and National Science Council (NSC 98-2923-B-019002), Taiwan. BV and BW acknowledge the Mahidol University, Thailand, for the seeding fund for visiting scholars, 2014.

\section{References}

[1] Soto-Rodriguez SA, Roque A, Lizarraga-Partida ML, Guerra-Flores AL, Gomez Gil B. Virulence of luminous vibrios to Artemia franciscana nauplii. Dis Aquat Organ 2003;53:231-40.

[2] Tran L, Nunan L, Redman RM, Mohney LL, Pantoja CR, Fitzsimmons K, et al. Determination of the infectious nature of the agent of acute hepatopancreatic necrosis syndrome affecting penaeid shrimp. Dis Aquat Organ 2013;105: $45-55$.

[3] Sadok K, Faouzi L, Amina B. Characterization of Vibrio parahaemolyticus isolated from farmed sea bass (Dicentrarchus labrax) during disease outbreaks. Int Aquat Res 2013;5:13.

[4] Chakrabarti MK, Sinha AK, Biswas T. Adherence of Vibrio parahaemolyticus to rabbit intestinal epithelial cells in vitro. FEMS Microbiol Lett 1991;68:113-7.

[5] Enos-Berlage JL, McCarter LL. Relation of capsular polysaccharide production and colonial cell organization to colony morphology in Vibrio parahaemolyticus. J Bacteriol 2000:182:5513-20.

[6] Jaisi DP, Dong H, Kim J. Nontronite particle aggregation induced by microbial fe (III) reduction and exopolysaccharide production. Clays Clay Miner 2007:55:96-100.

[7] Rasmussen TB, Givskov M. Quorum-sensing inhibitors as anti pathogenic drugs. Int J Med Microbiol 2006;296:149-61.

[8] Jiang P, Li J, Han F, Duan G, Lu X, Gu Y. Antibiofilm activity of an exopolysaccharide from marine bacterium Vibrio sp. QY101. PLoS One 2011;6. e18514.

[9] Defoirdt T, Boon N, Bossier P, Verstraete W. Disruption of bacterial quorum sensing: an unexplored strategy to fight infections in aquaculture. Aquaculture 2004:240:69-88.

[10] Tinh NTN, Dierckens K, Sorgeloos P, Bossier PN. N-acyl homoserine lactonedegrading microbial enrichment cultures isolated from Penaeus vannamei shrimp gut and their probiotic properties in Brachionus plicatilis cultures. FEMS Microbiol Ecol 2007;62:45-53.

[11] Moriarty DJW. Control of luminous Vibrio species in penaeid aquaculture ponds. Aquaculture 1998;164:351-8.

[12] Picchietti S, Mazzini M, Taddei AR, Renna R, Fausto AM, Mulero V, et al. Effects of administration of probiotic strains on GALT of larval gilthead seabream: immunohistochemical and ultrastructural studies. Fish Shellfish Immunol 2007:22:57-67.

[13] Leadbetter JR, Greenberg EP. Metabolism of acyl-homoserine lactone quorumsensing signals by Variovorax paradoxus. J Bacteriol 2000;182:6921-6.

[14] Vinoj G, Vaseeharan B, Brennan G. Green fluorescent protein visualization of Vibrio parahaemolyticus infections in Indian white shrimp Fenneropenaeus indicus (H Milne Edwards). Aquacult Res 2014;45(12):1989-99.

[15] Pratt LA, Kolter R. Genetic analysis of Escherichia coli biofilm formation: roles of flagella, motility, chemotaxis and type I pili. Mol Microbiol 1998;30: 285-93.

[16] Chen R, Zhou Z, Cao Y, Bai Y, Yao B. High yield expression of an AHL lactonase from Bacillus sp. B546 in Pichia pastoris and its application to reduce Aeromonas hydrophila mortality in aquaculture. Microb Cell Fact 2010;9:39.

[17] Swift S, Karlyshev AV, Fish L, Durant EL, Winson MK, Chhabra SR, et al. Quorum sensing in Aeromonas hydrophila and Aeromonas salmonicida: identification of the LuxRI homologs AhyRI and AsaRI and their cognate N-acylhomoserine lactone signal molecules. J Bacteriol 1997;179:5271-81.

[18] Morohoshi T, Inaba T, Kato N. Identification of quorum-sensing signal molecules and the LuxRI homologs in fish pathogen Edwardsiella tarda. J Biosci Bioeng 2004;98:274-81.

[19] Serebryakova EV, Darmov IV, Medvedev NP, Alekseev SM, Rybak SI. Evaluation of the hydrophobicity of bacterial cells by measuring their adherence to chloroform drops. Microbiology 2002;71:202-4.

[20] Favre-Bonte S, Kohler T, Delden CV. Biofilm formation by Pseudomonas aeruginosa: role of the C4-HSL cell-to-cell signal and inhibition by azithromycin. J Antimicrob Chemother 2003:52:598-604.

[21] Chu W, Lu F, Zhu W, Kang C. Isolation and characterization of new potential probiotic bacteria based on quorum-sensing system. Appl Microb 2010;110: $202-8$

[22] Trevors IS, Lusty CW. A base microcomputer program for calculating $\mathrm{LD}_{50}$ values. Water Air Soil Pollut 1985;24:431-42.

[23] Ellis AE. Lysozyme assays. In: Stolen JS, Fletcher TC, Anderson DP, Robertson BS, van Muiswinkel WB, editors. Techniques in fish immunology. Fair Haven NJ, USA: SOS Publications; 1990. p. 101-3.

[24] Su YC, Liu C. Vibrio parahaemolyticus: a concern of seafood safety. Food Microbiol 2007:24:549-58.

[25] Costerton JW. Biofilms: the bacterial way to persist, Abstracts book of the International symposium and the 43rd ESCMID post-graduate course - Bacterial adaptation mechanisms: biofilms, Hyper mutability and antibiotic resistance. 2007. p. 9.

[26] Marketon MM, Glenn SA, Eberhard GJE. Quorum sensing controls exopolysaccharide production in Sinorhizobium meliloti. J Bacteriol 2003;185: 325-31.

[27] Yuansha C, Jianli D, Morris JG, Johnson JA. Genetic analysis of the capsule polysaccharide (K antigen) and exopolysaccharide genes in pandemic Vibrio parahaemolyticus 03:K6. BMC Microbiol 2010;10:274.

[28] Wai SN, Mizunoe Y, Takade A, Kawabata S, Yoshida S. Vibrio cholerae 01 strain TSI-4 produces the exopolysaccharide materials that determine colony morphology, stress resistance, and biofilm formation. Appl Environ Microbiol 1998;64:3648-55.

[29] AbuSayem SM, Manzo E, Ciavatta L, Tramice A, Cordone A, Zanfardino A, et al Anti-biofilm activity of an exopolysaccharide from a sponge-associated strain of Bacillus licheniformis. Microb Cell Fact 2011;10:74.

[30] Gracia JA, Villarroel M. Effect of feed type and feeding frequency on macrophage functions in tilapia (Oreochromis niloticus L.). Fish Shellfish Immunol 2009;27:325-9. 
[31] Sun YZ, Yang HL, Ma RL, Lin WY. Probiotic applications of two dominant gut Bacillus strains with antagonistic activity improved the growth performance and immune responses of grouper Epinephelus coioides. Fish Shellfish Immunol 2010;29:803-9.

[32] Kim DH, Austin B. Innate immune responses in rainbow trout (Oncorhynchus mykiss, Walbaum) induced by probiotics. Fish Shellfish Immunol 2006;21: 513-24.
[33] Liu CH, Cheng CH, Wang SW, Cheng W. Dietary administration of the probiotic, Bacillus subtilis E20, enhances the growth, innate immune responses, and disease resistance of the grouper, Epinephelus coioides. Fish Shellfish Immunol 2012;33:699-706. 